\title{
ANALISIS BREAKTHROUGH CURVE UNTUK KARAKTERISTERISASI PELORONGAN DI SISTEM SUNGAI BAWAH TANAH PINDUL KABUPATEN GUNUNGKIDUL
}

\author{
BREAKTHROUGH CURVE ANALYSIS FOR PASSAGE \\ CHARACTERISATION IN PINDUL UNDER GROUND RIVER \\ SYSTEM
}

\author{
Ahmad Cahyadi ${ }^{1}$, Romza Fauzan Agniy ${ }^{2}$ \\ 1'Departemen Geografi Lingkungan Fakultas Geografi Univeristas Gadjah Mada, ahmadcahyadi@geo.ugm.ac.id \\ ${ }^{2}$ Departemen Geografi Lingkungan Fakultas Geografi Univeristas Gadjah Mada
}

\begin{abstract}
ABSTRAK
Karakteristik hidrogeologi sistem sungai bawah tanah di kawasan karst sangat penting untuk didefinisikan dalam rangka untuk mendukung perencanaan pengelolaannya di masa mendatang. Namun demikian, lorong-lorong sungai bawah tanah di kawasan karst tidak semuanya dapat dengan mudah dipetakan karena berbagai kendala berupa lorong yang sempit, terdapat kolam yang dalam dan keberadaan lorong yang penuh dengan air, sehingga pendefinisian sistem hidrogeologi suatu kawasan karst menjadi sulit dilakukan. Penelitian ini dilakukan untuk (1) mengetahui keterhubungan antara Goa Sioyot dengan Goa Pindul, dan (2) menganalisis karakteristik pelorongan sistem sungai bawah tanah berdasarkan pada breakthrough curve hasil uji tracer. Uji tracer dilakukan dengan menggunakan serbuk uranin yang dilarutkan dan dituangkan pada aliran sungai bawah tanah di Goa Sioyot, sedangkan pencatatan breakthrough curve dilakukan dengan menggunakan Fluorometer yang diletakkan di Goa Pindul. Hasil analisis menunjukkan bahwa (1) sungai bawah tanah di Goa Sioyot memiliki keterhubungan dengan sungai bawah tanah di Goa Pindul dan (2) sistem kelorongan yang berkembang pada sungai bawah tanah di antara Goa Sioyot dan Goa Pindul dikontrol oleh lorong conduit dan lorong diffuse. Baik lorong conduit ataupun diffuse memiliki peranan yang sama besar yang nampak dari dua puncak konsentrasi uranin dalam aliran yang
\end{abstract}

terbentuk pada breakthrough curve hasil pencatatan Fluorometer.

Kata Kunci: Breakthrough Curve, Pelorongan, Uji Tracer, Karst, Sungai Bawah Tanah

\section{PENDAHULUAN (INTRODUCTION)}

Pemahaman akan kondisi hidrogeologi suatu kawasan menjadi sangat penting dalam upaya pengelolaan sumberdaya khususnya sumberdaya airtanah (Bakalowicz, 2011; Worthington, 2011; Cahyadi dkk., 2013). Kajian ini akan sangat membantu terkait analisis simpanan air di kawasan karst yanng dapat dimanfaatkan, analisis pengelolaan khususnya terkait dengan perlindungan airtanah dari polutan/ bahan pencemar serta perencanaan pengelolaan wilayah (Leibundgut et al., 2009).

Kawasan karst adalah kawasan yang berkembang akibat dominannya proses pelarutan. Berkembangnya porositas sekunder di kawasan karst menyebabkan wilayah ini memiliki karakteristik yang unik sekaligus memberikan tantangan tersendiri bagi pengelolaannya (Kresik, 2013). Zona anisotropis di mana aliran sulit diprediksi arah dan karakteristiknya menyebabkan kawasan karst seringkali belum dikelola sebagaimana mestinya.

Tipe aliran di kawasan karst secara garis besar dibedakan menjadi 2, yakni aliran airtanah melalui rongga antar butir batuan yang disebut diffuse dan aliran airtanah yang melalui celah 
atau lorong pelarutan yang disebut konduit. Meskipun demikian, banyak ahli yang kemudian menambahkan jenis antara keduanya yang melalui lorong yang relatif kecil dengan sebutan fissure. Masing-masing tipe aliran ini memiliki konsekuensi yang besar bagi sifat aliran, karakteristik hidrogeokimia dan karakteristik simpanan air di kawasan karst (White, 1989; Hess dan White, 1989).

Dominasi porositas sekunder dan sifat anisotropis di kawasan karst menyebabkan batas hidrologi dan batas topografi seringkali sama sekali tidak terkait (Milanović, 2004). Hal ini berbeda dengan wilayah lain yang didominasi porositas primer, di mana batas hidrologi seringkali sama dengan batas hidrologi berupa igir pegunungan (La Moreaux dan Daoxian, 2004). Oleh karenanya diperlukan suatu pendekatan yang dapat digunakan untuk mendefinisikan karakterisitik daerah tangkapan air dari sungai bawah tanah dan mataair untuk dapat menyusun suatu rencana pengelolaannya (Cahyadi dkk., 2013).

Awalnya banyak model yang dikembangkan di kawasan karst lebih berupa "Black Box", namun seiring dengan perkembangan kajian dan kepentingan, maka kemudian banyak pula metode yang menganalisisi sistem hidrologi kawasan karst dengan model "Grey Box", salah satunya adalah model invers modelling (Ford and Williams, 2007). Invers modelling adalah suatu metode yang dikembangkan berdasarkan asumsi bahwa karakteristik output yang dikeluarkan dari mata air atau sungai bawah tanah mencerminkan proses yang terjadi di dalamnya (Rehrl dan Birk, 2010). Karakteristik yang dimaksud dapat berupa debit (hidrograf), karakteristik hidrokimia air (karakteristik unsur tertentu, isotop, bahan pencemar dan natural tracer lain), respon aliran terhadap hujan dan respon aliran terhadap artificial tracer (Rehrl dan Birk, 2010). Gambar 1 menunjukkan ilustrasi dari Invers Modelling.

Tracer test atau sering pula disebut sebagai dye tracer adalah salah satu metode yang dapat digunakan dalam analisis invers modelling, dengan hasil yang cukup dapat diandalkan (Leibundgut et al., 2009; Gilli, 2015). Tracer test adalah metode yang digunakan untuk mengetahui hubungan (konektivitas) antara beberapa goa, ponor, sink hole, sungai bawah tanah dan mataair dengan memasukkan zat pelacak (dapat berupa padat ataupun cair) tertentu ke dalam aliran (Benischke et al., 2007; Singhal dan Gupta, 2010). Analisis invers modelling dapat dilakukan dengan melakukan analisis terhadap kurva yang terbentuk dari fungsi konsentrasi zat pelacak dengan waktu atau disebut breakthrough curve. Stanley et al. (1980) menjelaskan bahwa tracer dalam jenis yang cukup kompleks meliputi air panas, spora, substansi ionik, isotop yang stabil, zat radioaktif, gas, florokarbon, dan pewarna alami. Bahanbahan yang digunakan tidak sembarangan agar keuntungan yang diperoleh dari tracer test tidak diikuti dengan kerusakan lingkungan. Hal ini yang menjadi sebab banyaknya zat pelacak yang saat ini tidak diperbolehkan lagi untuk digunakan, misalnya radioaktif (Benischke et al., 2007). Beberapa jenis zat pelacak yang sering digunakan ditunjukkan oleh Tabel 1.

\section{Spring Catchment}
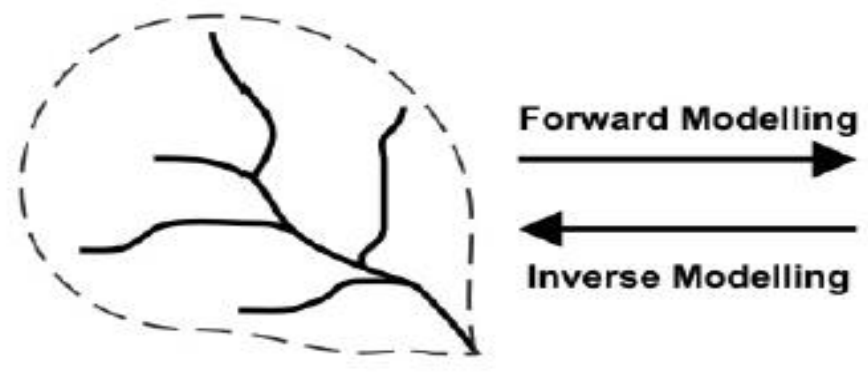

\section{Spring Response}

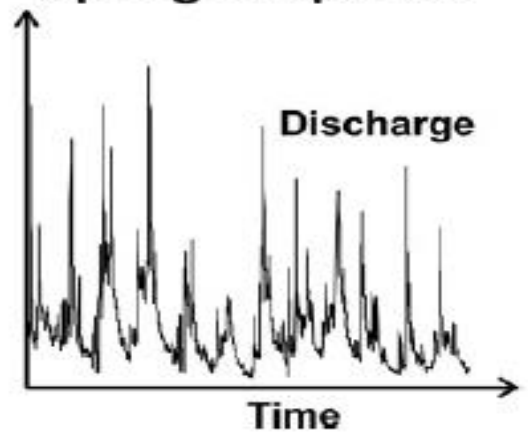

Gambar 1. Invers Model untuk Mengetahui Karakteristik Wilayah Tangkapan Air Pada Sungai Bawah Tanah atau Mataair (Rehrl dan Birk, 2010) 
Tabel 1. Beberapa Jenis Zat Pelacak yang Sering Digunakan

\begin{tabular}{|c|c|c|c|c|c|c|}
\hline No & Tracer & Jenis & $\begin{array}{c}\text { Batas } \\
\text { Deteksi } \\
(\mu \mathrm{g} / \mathrm{L})\end{array}$ & $\begin{array}{c}\text { Natural } \\
\text { Background }\end{array}$ & Toksikologi & Permasalahan \\
\hline 1 & Uranin & $\begin{array}{c}\text { Fluorescent } \\
\text { dyes }\end{array}$ & $10^{-1}$ & \multirow{8}{*}{ Tidak Ada } & \multirow[b]{2}{*}{ Aman } & \multirow{2}{*}{$\begin{array}{c}\text { Mudah } \\
\text { Terlarut pada } \\
\text { pH rendah } \\
\text { dan Sensitif } \\
\text { Terhadap } \\
\text { Cahaya }\end{array}$} \\
\hline 2 & Eosin & $\begin{array}{c}\text { Fluorescent } \\
\text { dyes }\end{array}$ & \multirow{5}{*}{$10^{-2}$} & & & \\
\hline 3 & Sulforhodamine B & $\begin{array}{c}\text { Fluorescent } \\
\text { dyes }\end{array}$ & & & $\begin{array}{c}\text { Ecotox,Tidak } \\
\text { Aman }\end{array}$ & \\
\hline 4 & Amidorhodamine $\mathrm{G}$ & $\begin{array}{c}\text { Fluorescent } \\
\text { dyes }\end{array}$ & & & Aman & \\
\hline 5 & Rhodamine WT & $\begin{array}{c}\text { Fluorescent } \\
\text { dyes }\end{array}$ & & & Genotoxic & \\
\hline 6 & Pyranine & $\begin{array}{c}\text { Fluorescent } \\
\text { dyes }\end{array}$ & & & \multirow{5}{*}{ Aman } & $\begin{array}{c}\text { Not Reliable } \\
\text { (Mengalami } \\
\text { Degradasi) }\end{array}$ \\
\hline 7 & Napthionate & $\begin{array}{c}\text { Fluorescent } \\
\text { dyes }\end{array}$ & \multirow{2}{*}{$10^{-1}$} & & & \\
\hline 8 & Tinopal & $\begin{array}{c}\text { Fluorescent } \\
\text { dyes }\end{array}$ & & & & Mudah Larut \\
\hline 9 & Sodium & Garam & \multirow{7}{*}{$\begin{array}{c}\text { Tergantung } \\
\text { Metode, } \\
\text { biasanya } \\
\text { sekitar } 0,1 \\
\mu \mathrm{g} / \mathrm{L} \\
\text { sampai } \\
\text { dengan } \\
1 \mathrm{mg} / \mathrm{L}\end{array}$} & Tinggi & & \\
\hline 10 & Potasium & Garam & & Sedang & & \\
\hline 11 & Lithium & Garam & & $\begin{array}{l}\text { Sangat } \\
\text { Rendah }\end{array}$ & \multirow{4}{*}{$\begin{array}{c}\text { Aman pada } \\
\text { Batas } \\
\text { Tertentu }\end{array}$} & Mudah Larut \\
\hline 12 & Strontium & Garam & & Sedang & & \\
\hline 13 & Klorida & Garam & & Tinggi & & \\
\hline 14 & Bromida & Garam & & Rendah & & \\
\hline 15 & Iodida & Garam & & $\begin{array}{l}\text { Sangat } \\
\text { Rendah }\end{array}$ & $\begin{array}{c}\text { Belum } \\
\text { Dievaluasi }\end{array}$ & Tidak Stabil \\
\hline 16 & Spora & Partikel & \multirow{4}{*}{$\begin{array}{l}\text { Terdeteksi } \\
\text { sebagai } \\
\text { Partikel } \\
\text { Tunggal }\end{array}$} & \multirow{4}{*}{ Tidak Ada } & Aman & $\begin{array}{c}\text { Sulit } \\
\text { Dilakukan } \\
\text { Analisis } \\
\text { Kuantitatif }\end{array}$ \\
\hline 17 & Microspheres & Partikel & & & Aman & Analisis \\
\hline 18 & Spesific Bacteria & Partikel & & & & Membutuhkan \\
\hline 19 & Bacteriophages & Partikel & & & Dievaluasi & $\begin{array}{c}\text { Waktu yang } \\
\text { Lama }\end{array}$ \\
\hline
\end{tabular}

Sumber: Benischke et al. (2007) dan Behrens et al. (2001)

Penelitian ini bertujuan untuk (1) mengetahui keterhubungan antara Goa Sioyot dengan Goa Pindul, dan (2) menganalisis karakteristik pelorongan sistem sungai bawah tanah berdasarkan pada breakthrough curve hasil uji tracer. Penelitian ini adalah penelitian lanjutan yang dilakukan setelah dilakukannya pemetaan lorong gua, mataair, ponor dan sinking stream di lokasi kajian. Selain itu, penelitian ini adalah bagian dari penelitian besar terkait pengelolaan sumberdaya air di Goa Pindul untuk mendukung perencanaan pengelolaan pariwisata berbasis karakteristik sumberdaya dan pengirangan risiko bencana.

\section{LOKASI PENELITIAN (STUDY AREA),}

Penelitian ini dilakukan di sistem sungai bawah tanah Pindul yang secara administrasi masuk di Desa Bejiharjo, Kecamatan Karangmojo, Kabupaten Gunungkidul, Daerah Istimewa Yogyakarta. Secara fisografis, lokasi terletak pada Cekungan Wonosari (Gambar 2). 


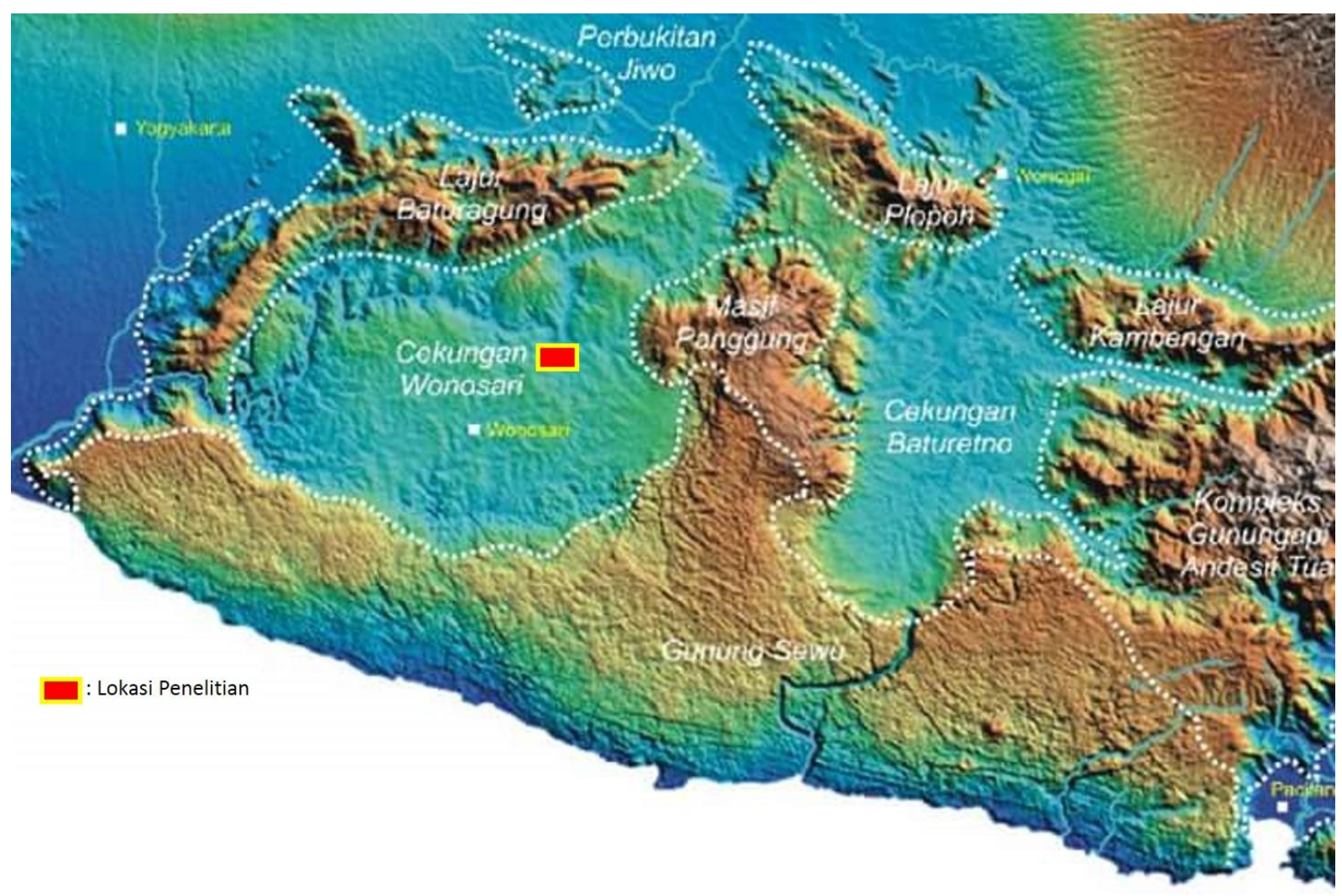

Gambar 2. Letak Lokasi Kajian

Lokasi kajian memiliki topografi berbukit dengan berbagai bentukkan khas kawasan karst berupa sinking stream, ponor, karst window, goa, mataair karst, conical hill, dan sungai bawah tanah. Batuan penyusun berupa batuan gamping yang masuk dalam Formasi Wonosari. Batuan penyusun di lokasi ini sedikit berbeda dengan wilayah di sekitarnya yang merupakan batuan gamping Formasi Kepek, di mana pada Formasi Kepek bentukan khas kawasan karst relative tidak berkembang.

\section{METODE (METHODS)}

Alat dan bahan yang digunakan dalam penelitian ini meliputi peralatan uji tracer seperti zat pelacak dan fluoro meter yang digunakan untuk mencatat konsentrasi larutan zat pelazak dalam aliran. Zat pelacak yang digunakan dalam penelitian ini adalah uranin, yakni sejenis fluorescent dyes yang memiliki warna hijau dengan batas deteksi paling kecil dibandingkan yang lain yakni $10^{-1} \mu \mathrm{g} / \mathrm{L}$, paling cocok untuk pelacakan pada zona gelap (tidak terkena cahaya langsung) dan cocok untuk wilayah dengan $\mathrm{pH}$ air tinggi. Sebagai peralatan pendukung digutuhkan pita ukur dan current meter untuk menentukan debit aliran saat dilakukan injeksi zat pelacak.

Besarnya zat pelacak yang digunakan ditentukan berdasarkan Persamaan 1 (Käss, 1998; Goldscheider et al., 2008). Faktor yang menentukan banyaknya zat pelacak yang digunakan secara garis besar adalah jarak yang diperkirakan akan ditempuh zat pelacak dan debit aliran di mana zat pelacak diijeksikan. Setidaknya ada 33 persamaan yang telah dibuat untuk menentukan banyaknya zat pelacak yang harus diijeksikan dalam aliran agar dapat terdeteksi pada lokasi yang diharapkan (Field, 2003; 2005). 
$\mathbf{M}=\mathbf{L} \cdot \mathbf{k} . \mathbf{B}$

di mana $\mathrm{M}=$ Kuantitas zat Pelacak yang diperlukan $(\mathrm{Kg}), \mathrm{k}=$ koefisien zat pelacak yang digunakan (nilai k untuk unranine adalah 1) dan $\mathrm{B}=$ faktor kondisi hidrogeologi (biasanya bernilai $0,1-0,9)$. Nilai $\mathrm{k}$ dan $\mathrm{B}$ dapat dilihat pada Tabel 2.

Injeksi zat pelacak di lakukan di Goa Sioyot sebagai lokasi yang diperkirakan berada di bagian hulu. Injeksi dilakukan pada aliran sungai bawah tanah. Pencatat fluoro meter dipasang di Goa Pindul yang diperkirakan terletak di bagian hilir. Selain itu, dipasang pula karbon aktif pada beberapa mataair yang terletak di lokasi kajian untuk mengetahui apakah terdapat koneksi antara sungai bawah tanah di Goa Sioyot dengan masing-masing mataair. Pencatatan dengan menggunakan karbon aktif hanya akan menunjukkan adanya konektivitas ataukah tidak, namun tidak akan mengahasilkan data breakthrough curve. Hal ini dilakukan karena keterbatasan jumlah fluoro meter yang digunakan oleh peneliti. Gambar 3 menunjukkan lokasi Goa Pindul, Goa Sioyot dan beberapa mataair dan goa di sekitarnya.

Analisis konektivitas antara Goa Sioyot dan Goa Pindul ditentukan dari terdeteksi atau tidaknya uranin yang diinjeksikan di Goa Sioyot oleh Fluorometer di Goa Pindul. Kemudian analisis terkait dengan karakteristik pelorongan dalam penelitian ini dilakukan berdasarkan karakteristik breakthrough curve. Analisis terhadap breakthrough curve dalam penelitian ini hanya dilakukan secara deskriptif berdasarkan pada hasil kajian dari penelitipeneliti terdahulu.

Tabel 2. Penentuan Nilai Koefisien Zat Pelacak (k) dan Faktor Kondisi Hidrogeologi (B)

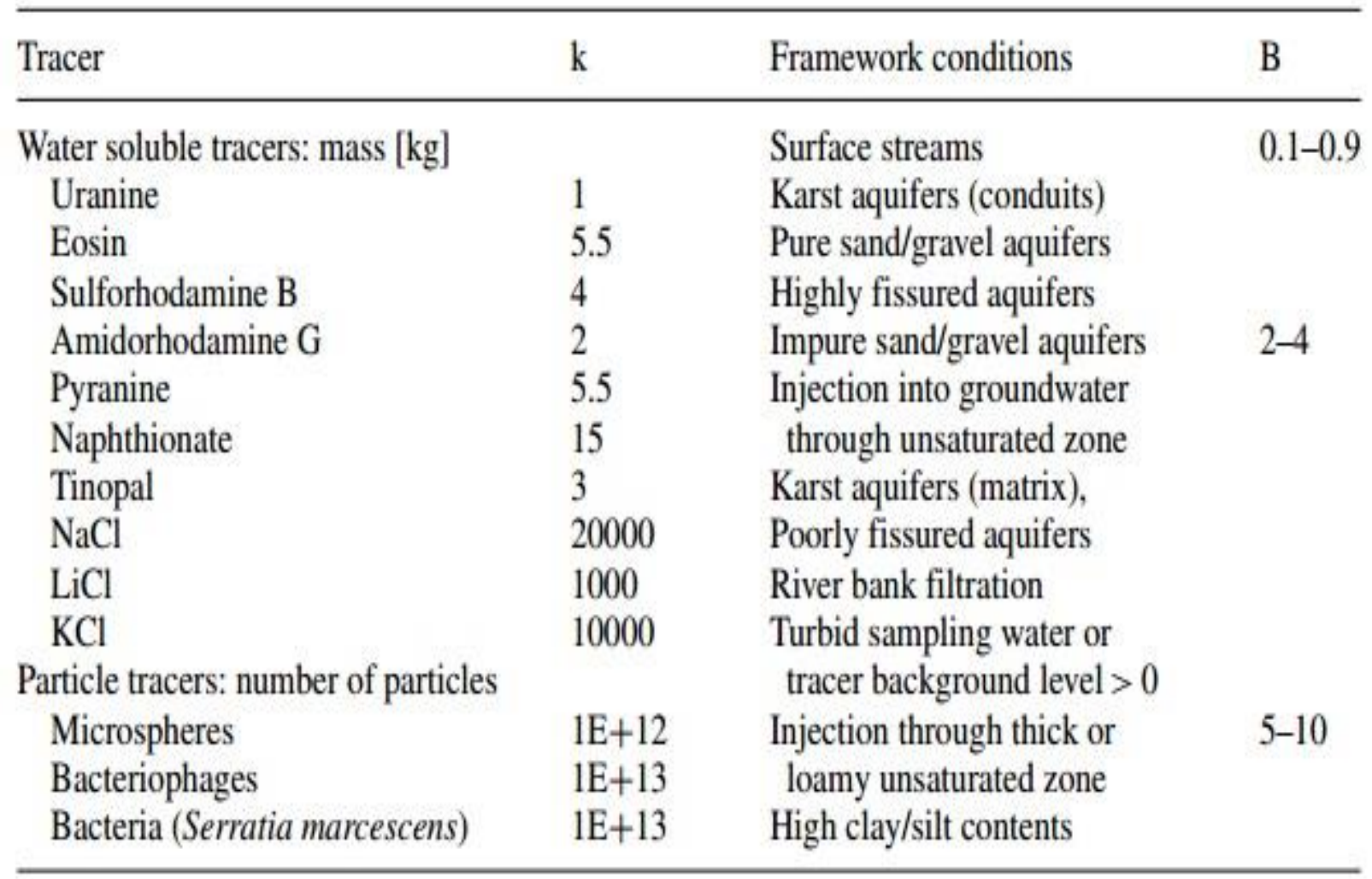

Sumber: Käss (1998); Goldscheider et al., 2008 


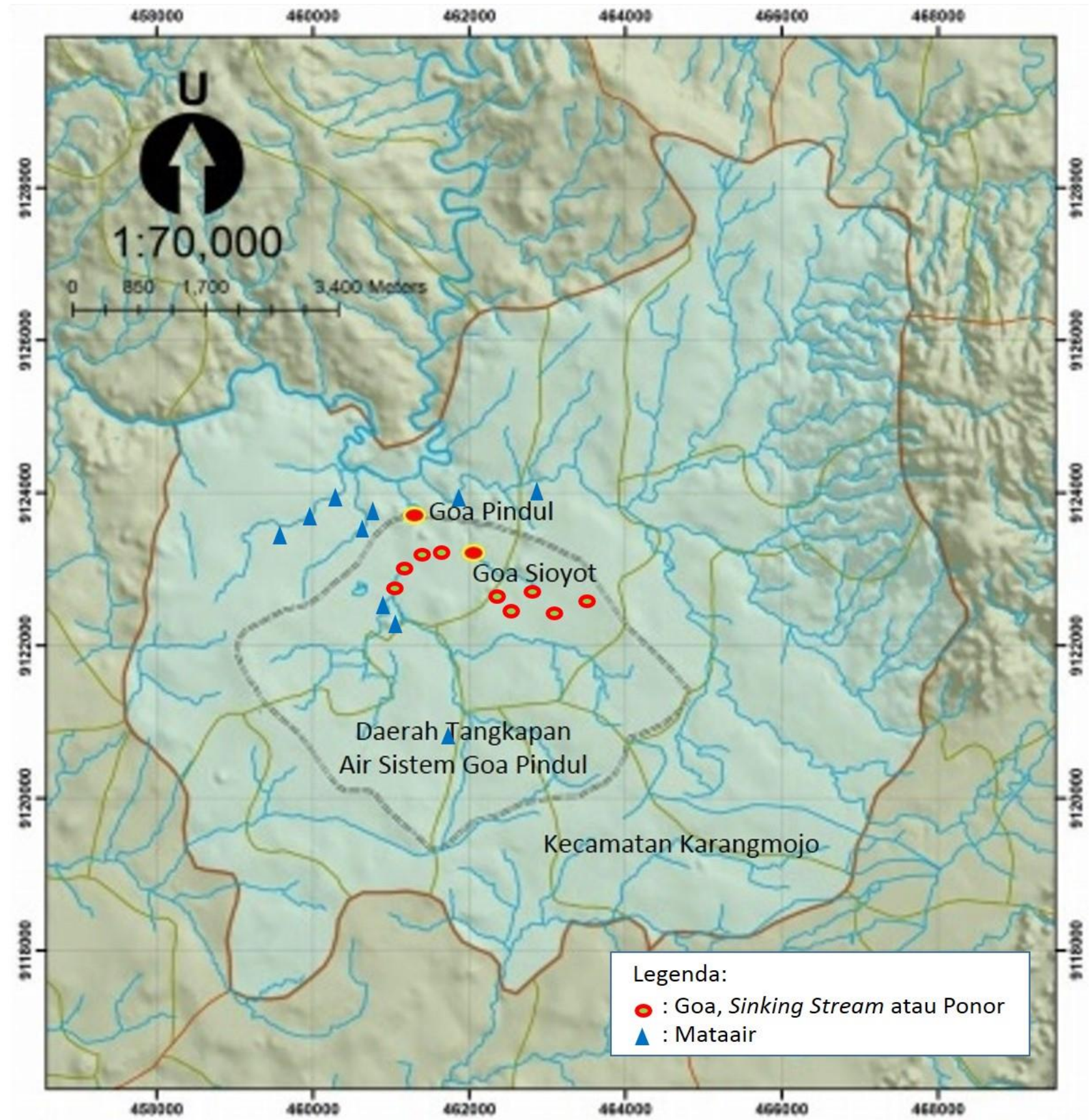

Gambar 3. Lokasi Goa Pindul, Goa Sioyot dan Beberapa Mataair serta Goa di Sekitarnya

\section{HASIL DAN PEMBAHASAN (RESULT AND DISCUSIONS)}

Hasil uji tracer yang dilakukan dengan uranin menunjukkan bahwa Goa Sioyot dan Goa Pindul positif terkoneksi. Hal ini nampak dari hasil pencatatan pada fluorometer serta kenampakkan visual pada aliran sungai bawah tanah di Goa Pindul (Gambar 4a.). Selain keluar di Goa Pindul, uranin secara visual nampak pula muncul di Mataair Ngancar (Gambar 4b) yang kemudian masuk ke dalam sinking stream yang menuju ke arah Goa Pindul. Hal ini nampak dari waktu kemunculan uranin di Mataair Ngancar yang lebih awal dibandingkan dengan waktu kemunculan di Goa Pindul. Berdasarkan pada hasil pelacakan yang telah dilakukan, maka konektivitas antara Goa Sioyot dan Goa Pindul 
secara sederhana dapat di sajikan seperti pada Gambar 5.

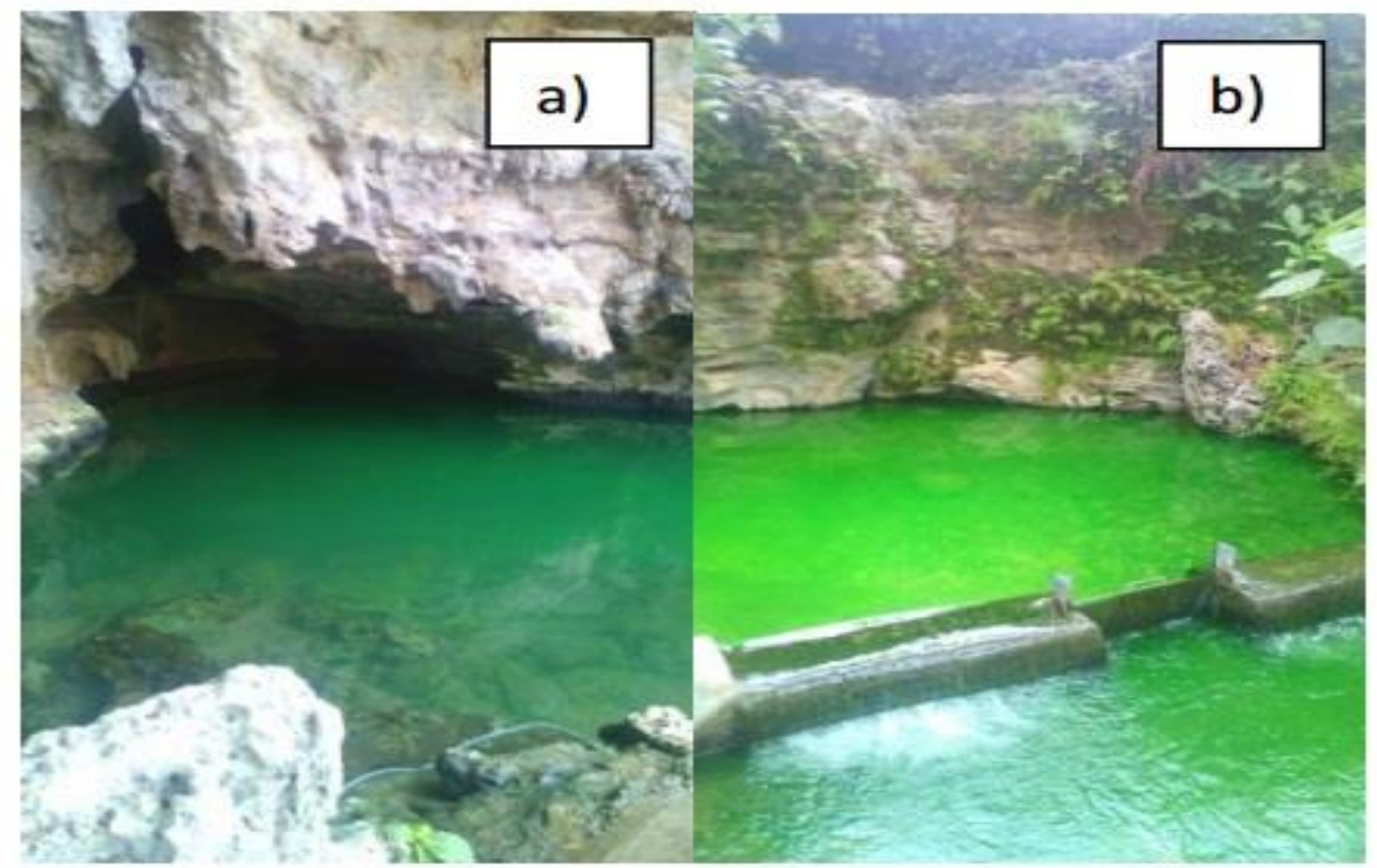

Gambar 4. Kemunculan Uranin yang Nampak Secara Visual di Goa Pindul (a) dan Mataair Ngancar (b)

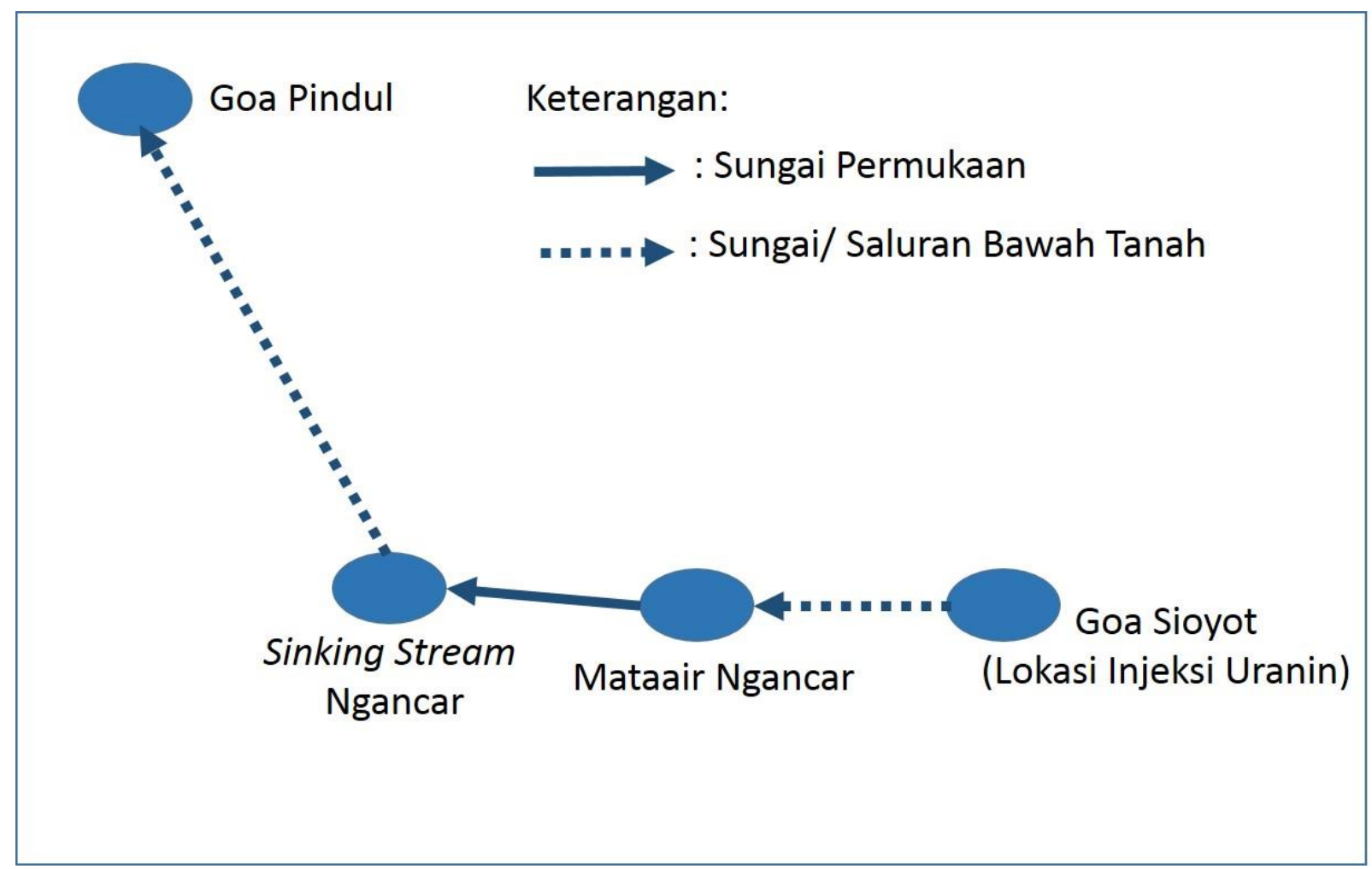

Gambar 5. Sketsa Konektivitas Sistem Sungai Bawah Tanah Antara Goa Sioyot dan Goa Pindul 
Breakthrough curve yang terbentuk dari hasil pencatatan fluorometer (Gambar 6) menunjukkan terdapat dua puncak dengan karakteristik yang berbeda. Bagian awal breakthrough curve berbentuk kurva lancip dengan waktu menuju konsentrasi puncak sangat cepat dan menurun dengan cepat pula, sedangkan kurava kedua (kanan) berbentuk kurva yang landau yang menunjukkan waktu menuju ke puncak relatif lambat dibandingkan dengan kurava pertama. Kurva breakthrough curve yang lancip pada Gambar 6 menunjukkan perkembangan lorong konduit yang menyebabkan terjadinya respon aliran yang cepat, sedangkan kurva yang melandai menunjukkan adanya perkembangan yang jauh berbeda, yakni aliran fissure dan/atau diffuse.

Beberapa peneliti sebelumnya seperti Benischke et al. (2007), Goldscheider et al. (2008), Gilli (2015) menyebutkan bahwa kemunculan dua puncak pada breakthrough curve disebabkan oleh adanya percabangan. Gambar 7 menunjukkan dua breakthrough curve dengan dua puncak. Hasil penelitian dan pemetaan jaringan goa dan sungai bawah tanah selanjutnya terkait dengan sistem yang membentuknya menunjukkan bahwa Goa Fort's Funnel dan Mataair Buffalo memiliki percabangan pada sistem sungai bawah tanahnya (Goldscheider et al. 2008). Berdasrkan hal tersebut maka kemudian diketahui bahwa sistem sungai bawah tanah antara Goa Sioyot dan Goa Pindul dikontrol oleh dua lorong, di mana saluran yang memisah kemudian kembali ke saluran utama seperti yang ditunjukkan Gambar 8 huruf I). Breakthrough curve yang terbentuk juga menunjukkan bahwa satu saluran pada sistem yang dikkaji memiliki karakteristik berupa saluran conduit, sedangkan yang satu berupa salura diffuse dan/atau fissure.

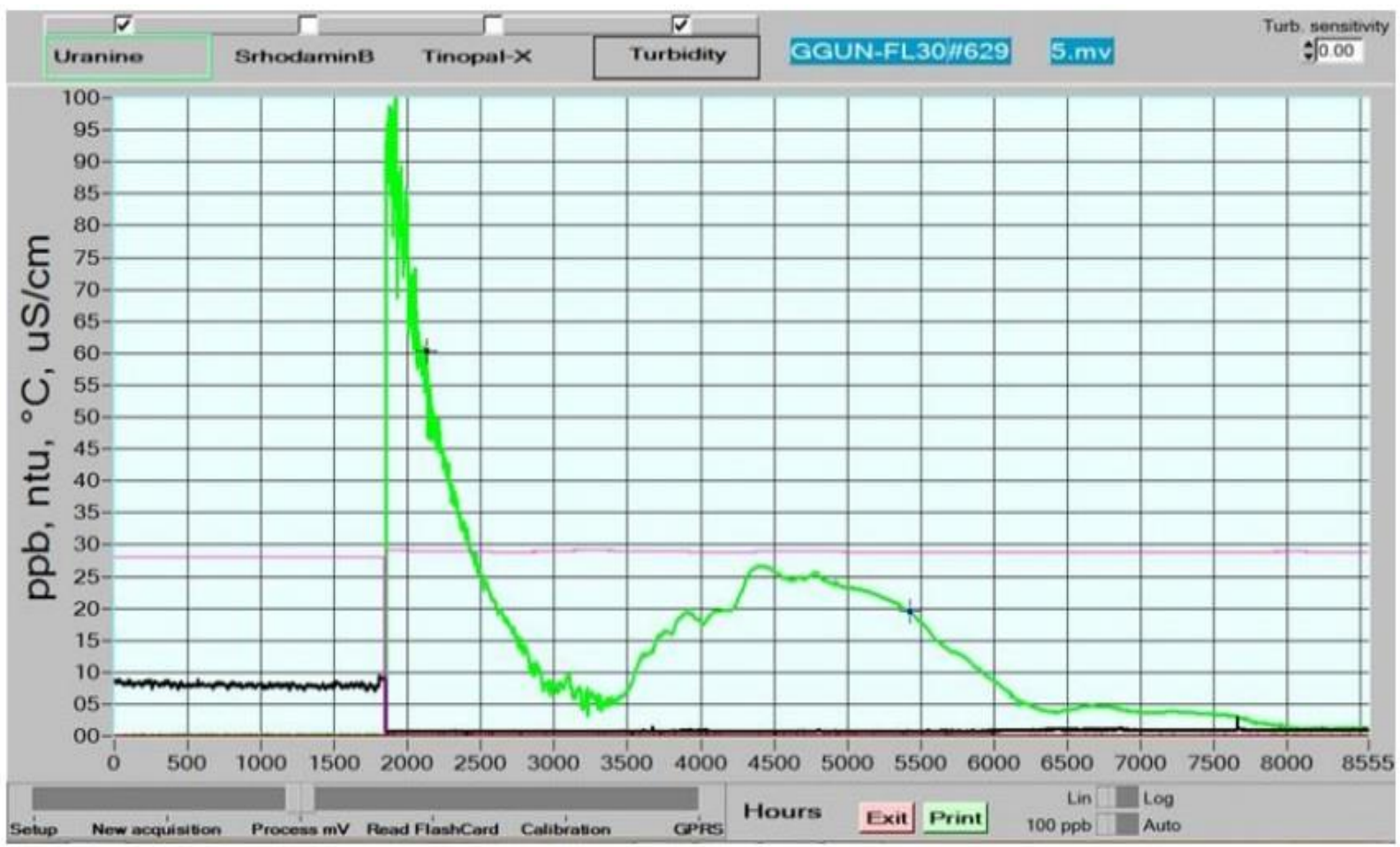

Gambar 6. Breakthrough Curve yang Terbentuk Hasil Tracer Test

di Sistem Sungai Bawah Tanah Pindul 


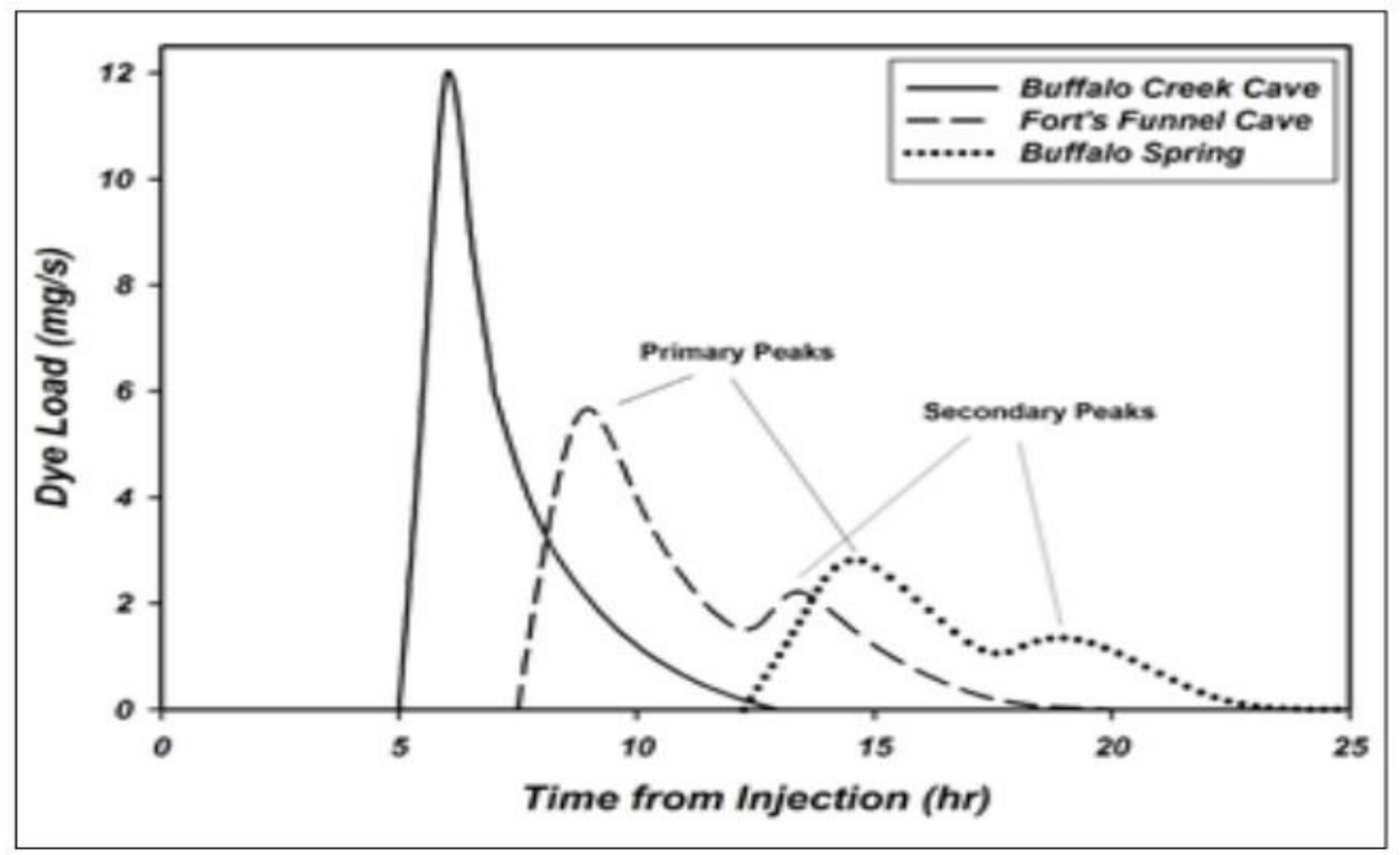

Gambar 7. Contoh Breakthrough Curve yang Dihasilkan oleh Percabangan Pelorongan (Goldscheider et al., 2008)

A

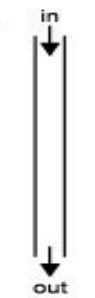

$Q_{\text {in }}=Q_{\text {out }}$

$M_{\text {in }}=M_{\text {out }}$

no dilution

dilution

no divergence convergence

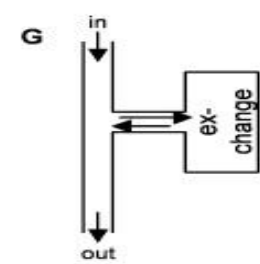

$Q_{\text {in }}=Q_{\text {out }}$

$M_{\text {in }}=M_{\text {out }}$

no dilution

no divergence

exchange

B

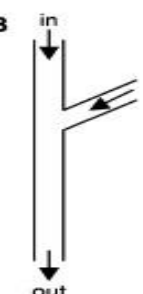

$Q_{\text {in }} \leq Q_{\text {out }}$

$M_{\text {in }}=M_{\text {out }}$

Gambar 8. Berbagai Jenis Tipe c

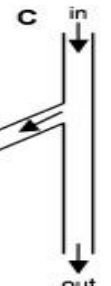

$Q_{\text {in }} \geq Q_{\text {out }}$

$M_{\text {in }} \geq M_{\text {out }}$

divergence no dilution

H

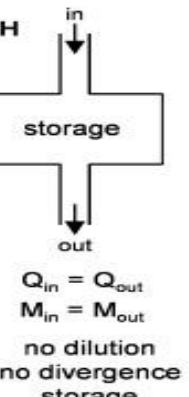

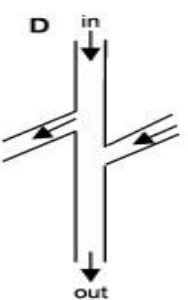

$Q_{\text {in }} \neq Q_{\text {out }}$

$M_{\text {in }} \geq M_{\text {out }}$

divergence convergence dilution

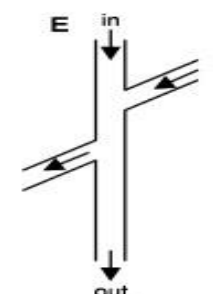

$Q_{\text {in }} \neq Q_{\text {ous }}$

$M_{\text {in }} \geq M_{\text {out }}$

convergence divergence dilution

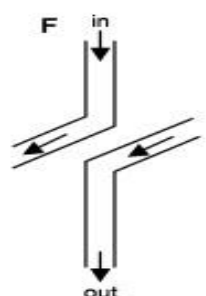

$Q_{\text {in }} \neq Q_{\text {out }}$

$\mathrm{O}=\mathrm{M}_{\text {out }}$

deviation no connection

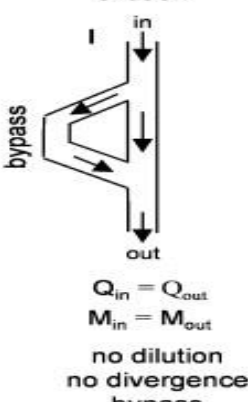

(Goldscheider et al., 2008) 


\section{KESIMPULAN (CONCLUSION)}

Hasil analisis yang dilakukan menunjukkan bahwa Goa Sioyot dan Goa Pindul positif memiliki konekvitas. Konektivitas antara keduanya diduga berupa pelorongan yang bercabang dengan sifat yang berbeda yakni pelorongan berupa konduit dan diffuse. Lorong Konduit akan memiliki respon yang cepat terhadap injeksi artificial tracer ataupun hujan, sedangkan sistem diffuse akan memiliki respon yang relatif lambat namun berarti memungkinkan adanya simpanan airtanah di dalamnya.

\section{DAFTAR PUSTAKA (REFERENCES)}

Bakalowicz, M. 2011. Management of Karst Groundwater Resources. dalam van Beynen, P.E. (ed). 2011. Karst Management. Dordrecht: Springer.

Behrens, H., Beims, U., Dieter, H., Dietze, G., Eikmann, T., Grummt, T., Hanisch, H., Henseling, H., Käss, W., Kerndorff, H., Leibundgut, C., Müller-Wegener, U., Rönnefahrt, I., Scharenberg, B., Schleyer, R., Schloz, W. dan Tilkes, F. 2001. Toxicological and Ecotoxicological Assessment of water Tracer. Hydrogeology Journal, 9: 321-325.

Benischke, R., Goldsceider, N., dan Smart, C. 2007. Tracer Techniques. dalam Goldsceider, N., dan Drew, D (eds). 2007. Methods in Karst Hydrogeology. London: Taylor \& Francis Group.

Cahyadi, A., Pratiwi, E.S. dan Fatchurohman, H. 2013. Metode-metode Identifikasi Karakteristik Daerah Tangkapan Air Sungai Bawah Tanah dan Mataair Kawasan Karst: Suatu Tinjauan. dalam Marfai, M.A. dan Widyastuti, M. 2013. Pengelolaan Lingkungan Zamrud Khatulistiwa. Yogyakarta: Pintal.

Field, M.S. 2003. A Review of Some Tracer-Test Design Equations for Tracer-Mass Estimation and Sample-Collection
Frequency. Environmental Geology, 43: 867-881.

Field, M.S. 2005. Tracer-Test Design for Losing Stream-Aquifer Systems. International Journal of Speleology, 35(1): 25-36.

Ford, D. dan Williams, P. 2007. Karst Hydrology and Geomorphology. Chichester, West Sussex: John Wiley and Sons, Ltd.

Gilli, E. 2015. Karstology - Karst, Caves and Springs: Elements of Fundamental and Applied Karstology. Boca Raton: CRC Press.

Goldscheider, N., Meiman, J., Pronk, M dan Smart, C. 2008. Tracer Tests in Karst Hydrogeology and Speleology. International Journal of Speleology, 37 (1): 27-40.

Hess, J.W. dan White, W.B. 1989. Chemical Hydrology. dalam White, W.B. dan White, E.L (eds). 1989. Karst Hydrology: Concepts from the Mammoth Cave Area. New York: Springer.

Käss, W. 1998. Tracing Technique in Geohydrology. Rotterdam: Balkema.

Kresic, N. 2013. Water in Karst: Management, Vulnerability and Restoration. New York: Mc Graw Hill.

LaMoreaux, P.E. dan Daoxian, Y. 2004. Hydrogeology of Carbonate Rocks. dalam Kovalevsky, V.S., Kruseman, G.P. dan Rushton, K.R. 2004. Groundwater Studies: An International Guide for Hydrogeological Investigation. Paris: UNESCO.

Leibundgut, C., Maloszewski, P. dam Külls, C. 2009. Tracer Hydrology. New York: WileyBlackwell.

Milanović, P.T. 2004. Water Resources Engineering in Karst. Boca Raton: CRC Press.

Riehl, C. dan Birk, S. 2010. Hydrogeological Characterisation and Modelling of Spring 
Prosiding Pertemuan Ilmiah Tahunan Ke-1 Perhimpunan Ahli Airtanah Indonesia (PIT-PAAI) Bandung, 16 - 17 November 2016 Halaman 375 - 385

Chatchments in a Changing Environment. Austrian Journal of Earth Sciences, 103 (2), 106-117.

Singhal, B.B.S. dan Gupta, R.P. 2010. Applied Hydrogeology of Fractured Rocks. Dordrecht: Springer.

Stanley, N.D., Thomson, G.M., Bentley, H.W. dan Styles, G. 1980. Groundwater Tracer: A Short Review. Groundwater Journal, 18(1): 14-21.
White, E.L. 1989. Flood Hydrology. dalam White, W.B. dan White, E.L (eds). 1989. Karst Hydrology: Concepts from the Mammoth Cave Area. New York: Springer.

Worthington, S.R.H. 2011. Management of Carbonate Aquifers. dalam van Beynen, P.E. (ed). 2011. Karst Management. Dordrecht: Springer. 